\title{
Gene-edited animals face US regulatory crackdown
}

Last-minute proposal from Obama administration addresses CRISPR and other cutting-edge technologies.

\section{Amy Maxmen}

19 January 2017 | Clarified: 19 January 2017

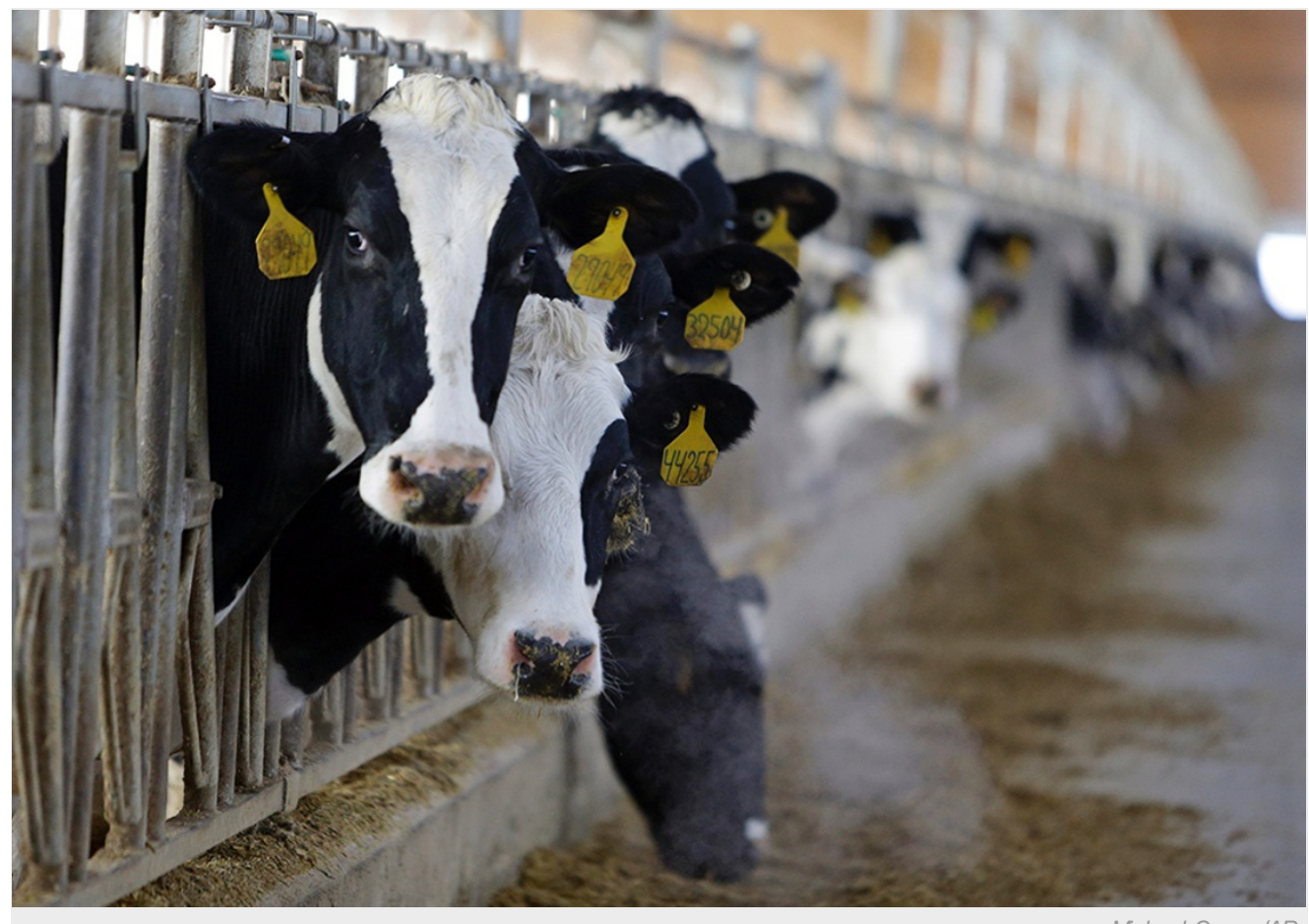

Michael Conroy/AP

Some dairy cattle have their horns removed, a practice that has raised animal-welfare concerns.

Researchers transforming animals with the latest genome-engineering tools may be disappointed by draft rules released by the US Food and Drug Administration (FDA) on 18 January - two days before US President Barack Obama leaves office. It is not clear how the administration of incoming president Donald Trump will carry the proposals forward, however.

The most controversial of three proposed regulations declares that all animals whose genomes have been intentionally altered will be examined for safety and efficacy in a process similar to that for new drugs.

Many researchers had hoped that the FDA would be less stringent about evaluating organisms whose genomes have been edited with precise tools - such as CRISPR and a separate technique called TALENs - than it is for animals that have been given DNA from different species or created using less-sophisticated means. Alison van Eenennaam, an animal geneticist at the University of California, Davis, calls the draft FDA proposals "insane".

"The trigger for their regulation is whether the animal was intended to be made, and what does intention have to do with risk?" she says. "The risk has to do with the attributes of the product."

\section{Swimming upstream?}

Some scientists, including van Eenennaam, are afraid that the proposed rules would prompt businesses, universities and non-profit organizations to abandon development of genetically engineered animals. They see a cautionary tale in the genetically engineered salmon created by AquaBounty Technologies in the early 1990s.

The company — based in Maynard, Massachusetts — spent US\$60 million on developing the fish, an Atlantic salmon (Salmo salar) with genes from Chinook salmon (Oncorhynchus tshawytscha) that allow it to grow rapidly. But the firm had to wait 20 years for the FDA to review more than 50 studies demonstrating that the salmon posed no unusual risks before the agency approved the fish in November 2015. Even then, the salmon cannot be sold until the FDA decides whether it must be labelled as genetically modified. 
AquaBounty's story terrifies Scott Fahrenkrug, chief scientific officer at gene-editing company Recombinetics in St Paul, Minnesota. The firm has produced hornless dairy cattle by inserting a gene from naturally hornless beef cattle into a breed of the same species that is used in milk production. The animals could help to reduce the practice of surgical 'dehorning', a controversial practice that has raised animal-welfare concerns.

On 21 December, Recombinetics told the FDA that it intended to market food from its cows without FDA approval, and with a label reading 'generally recognized as safe'. The company's decision was bolstered by the US Department of Agriculture's announcement in April 2016 that it would forgo regulation of a mushroom that has been genetically modified to resist browning. The agency said that the fungus, which was created using the CRISPR-Cas9 method, did not require approval because it did not contain genes from other species. Recombinetics' cattle were also created without foreign genes, using TALENs.

\section{Enter Trump}

Fahrenkrug was taken aback by the FDA's new proposal, and says that the agency has "gone off the rails". "They're suggesting that an already existing allele we have been eating for thousands of years now needs to be evaluated for risk because we've intentionally put it into this cow's genome," he says.

The company plans to protest against the agency's plan to the incoming administration of president-elect Donald Trump, which will oversee finalization of any new regulations. The draft regulations will be open for public comment until 19 April, and the FDA may modify its approach according to the feedback it receives.

Others welcomed the Obama administration's last-minute overture. "The public is leery of genetic engineering of animals, in particular," says Jennifer Kuzma, a social scientist at North Carolina State University in Raleigh. "With gene editing we do see off-target effects, so it is wise on the part of the FDA to include all of these organisms in the near term while they build up data."

But having had her own transgenic projects frozen in the past owing to arguably baseless fears from the public and regulators, van Eenennaam disagrees. "Because of measures like this, almost everything in genetic engineering will have to be done by huge multinational companies," she says. "If the scientific community doesn't stand up and say this is crazy, we've done a disservice to innovation."

Nature I doi:10.1038/nature.2017.21331

\section{Clarifications}

Clarified:The story has been updated to reflect that Jennifer Kuzma is a social scientist. 